8. Grynyov B.V., Gurdzhian N.R., Zelenskaya O.V., Lyubynskiy V.R., Molchanova N.I., Tarasov V.A. $\mathrm{O}$ razlichnyih podhodah $\mathrm{k}$ vyirazheniyu characteristic tochnosti izmereniy svetovogo vyihoda organicheskih stsintillyatorov [About the different approaches to the expression of the characteristics of accuracy of measurement of light output of organic scintillators]. Metrolohiia ta prylady - Metrology and instrumentation, 2013, no. 5, pp. 20-27.
9. Faddeev M.A. Elementarnaya obrabotka rezultatov eksperimenta [Basic processing of the results of the experiment]. Nizhny Novgorod, Nizhny Novgorod State University Publ., 2010. 122 p.

10. Cirlina Ju.A. (Ed.). Report on scientific-research work: Development of methods and metrological assurance of quality control packed scintillation crystals. Kharkov, Institute of Single Crystals Publ., 1980. 118 p. (in Russian, unpublished).

\title{
Combined method of analytical control of concentration of combustible substances with preliminary oxidization in barrier discharge
}

\author{
G. M. Mamedov, S.M. Abbasova \\ Azerbaijan State University of Oil and Industry, Azadlig Avenue, 2, Az 1010, Baku, Azerbaijan \\ mamedov.gakhraman@mail.ru
}

\section{Abstract}

The combined method of analytical control of the concentration of combustible substances with preliminary oxidation in a barrier discharge is considered, where the analyzed substance is subjected to a combination of certain types of energy effects, which allows obtaining measurement information about the composition or physicochemical properties of the analyzed substance. In analytical practice, in a barrier discharge, ozone is synthesized in a device consisting of two coaxially located metal electrodes in the form of a tube and a rod separated by a dielectric from the pyrite glass, the gap of which is filled with air at the atmospheric pressure. The process of obtaining ozone in the device proceeds in two stages. At the first stage, endothermic dissociation of oxygen molecules occurs to atoms, and at the second (exothermic) stage, a reversible reaction of ozone formation occurs.

During electro-cracking in a gaseous hydrocarbon environment in a barrier discharge, hydrocarbon molecules are splitting to the radicals. The nature of the chemical reactions and, consequently, the composition of the reaction products are determined by the initial composition of the initial substances, their pressure, as well as the time of action of the electric discharge and its power. In the interaction of atomic oxygen with the products of the electro-cracking of molecules of the analyzed substance, the balance in ozone formation is disturbed, which leads to a decrease in the ozone concentration in the barrier discharge.

Changes in the concentration of ozone in the presence of vapors of liquid hydrocarbons and petroleum products in the air, directly in the ozone synthesizer, makes it possible to use the method of analytical control under consideration to determine the concentration of vapor-gas mixtures of combustible substances and petroleum products, as well as to measure saturated vapor pressure of liquid hydrocarbons, petroleum products and fuels.

Keywords: barrier discharge, oxidation, ozone, atomic oxygen, combustible substance, saturated vapor pressure, concentration.

Currently for determination of structure and properties of the analyzed substances, various methods of analytical control in which for the measurement of physical quantity a number of chemical and physical transformations of the analyzed substance takes place are applied. Application of similar methods of analytical control is connected with the intensive development of tool methods of analytical chemistry and problems arising at identification of substances in various branches of science and technology. Instrumental methods, namely, physical and physicochemical ones, have ample information opportunities, rapidity and can be used for analytical control of liquid and gaseous substances [1]. 
Proceeding from the above, the task of development of the combined methods allowing the effectively defining of the structure and properties of the analyzed substances has been set.

The combined method including two or three different methods or the scheme of simultaneous use of two or three different detectors with parallel or consecutive placement $[2,3,4]$ is most widely applied in a single chemical analysis system.

In this article, the combined method at which the analyzed substance is exposed to aggregate of certain types of energy impact that allows to obtain measuring information on the structure or physical and chemical properties of the analyzed substance is considered.

In the investigated combined method of analytical control of substances the defining condition is existence of the processes connected with oxidation of the analyzed substance in the barrier discharge in the homogeneous field. The simplest device working on the principle of the barrier discharge where in analytical practice ozone is synthesized represents two coaxially located metal electrodes divided by dielectric from pyrite glass in the form of a tube and a rod which gap is filled with air at an atmospheric pressure.

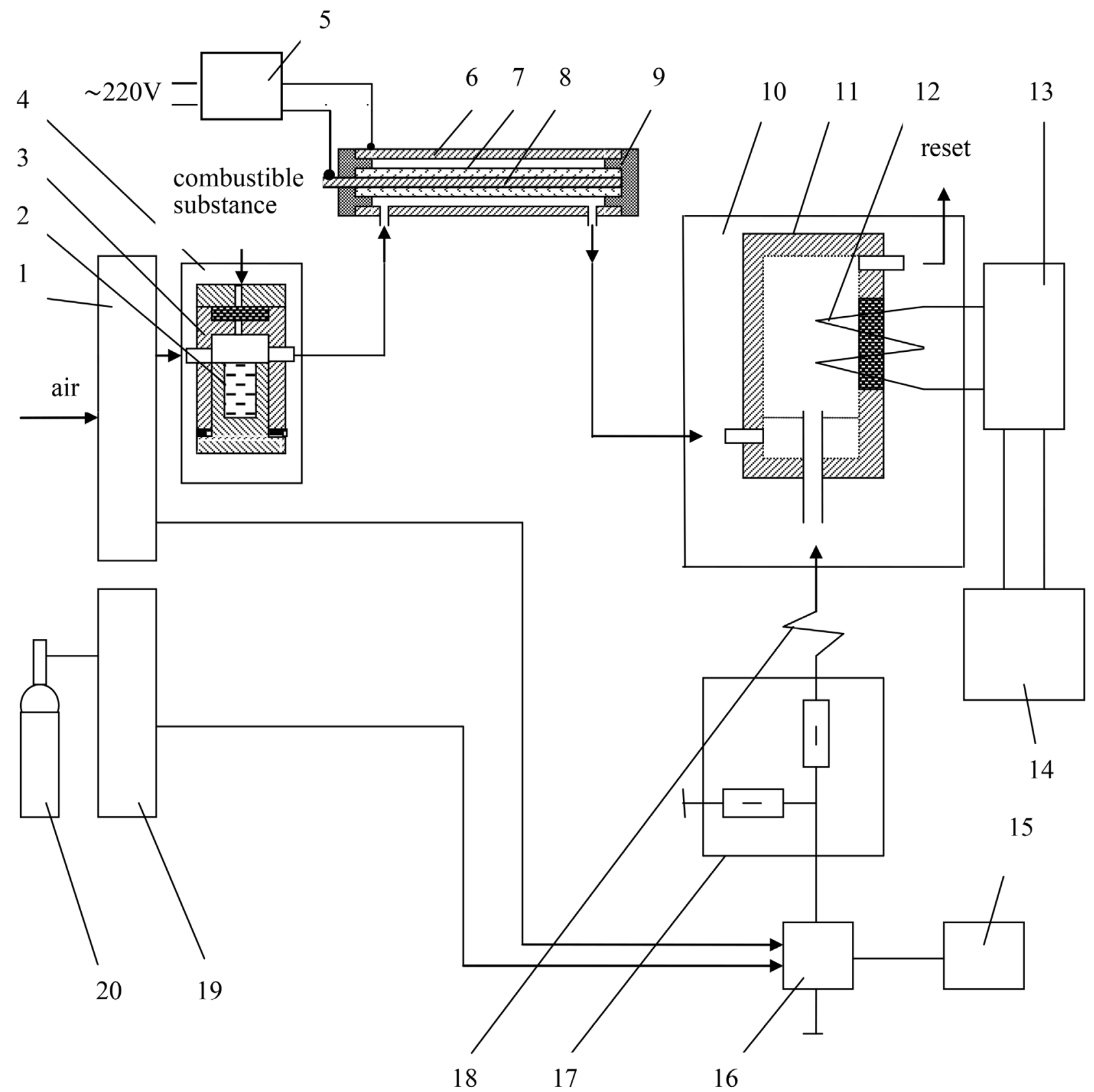

Fig. 1. Experimental facility

1 - air preparation unit, 2 - glass, 3 - evaporation chamber, 4 - thermostat, 5 - high-voltage transformer, 6 - electrodes in the form of a tube, 7 - dielectric made of pyrite glass, 8 - rod shaped electrodes, 9 - dielectric made of fluoroplastic, 10 - thermostat, 11 - measuring transducer, 12 - thermal converter, 13 - control unit, 14 - chart recorder, 15 - command device, 16 - automatic dispenser, 17 - divider of flow, 18 - hollow column, $19-$ unit for preparation of test substance, 20 - balloon with a test substance 


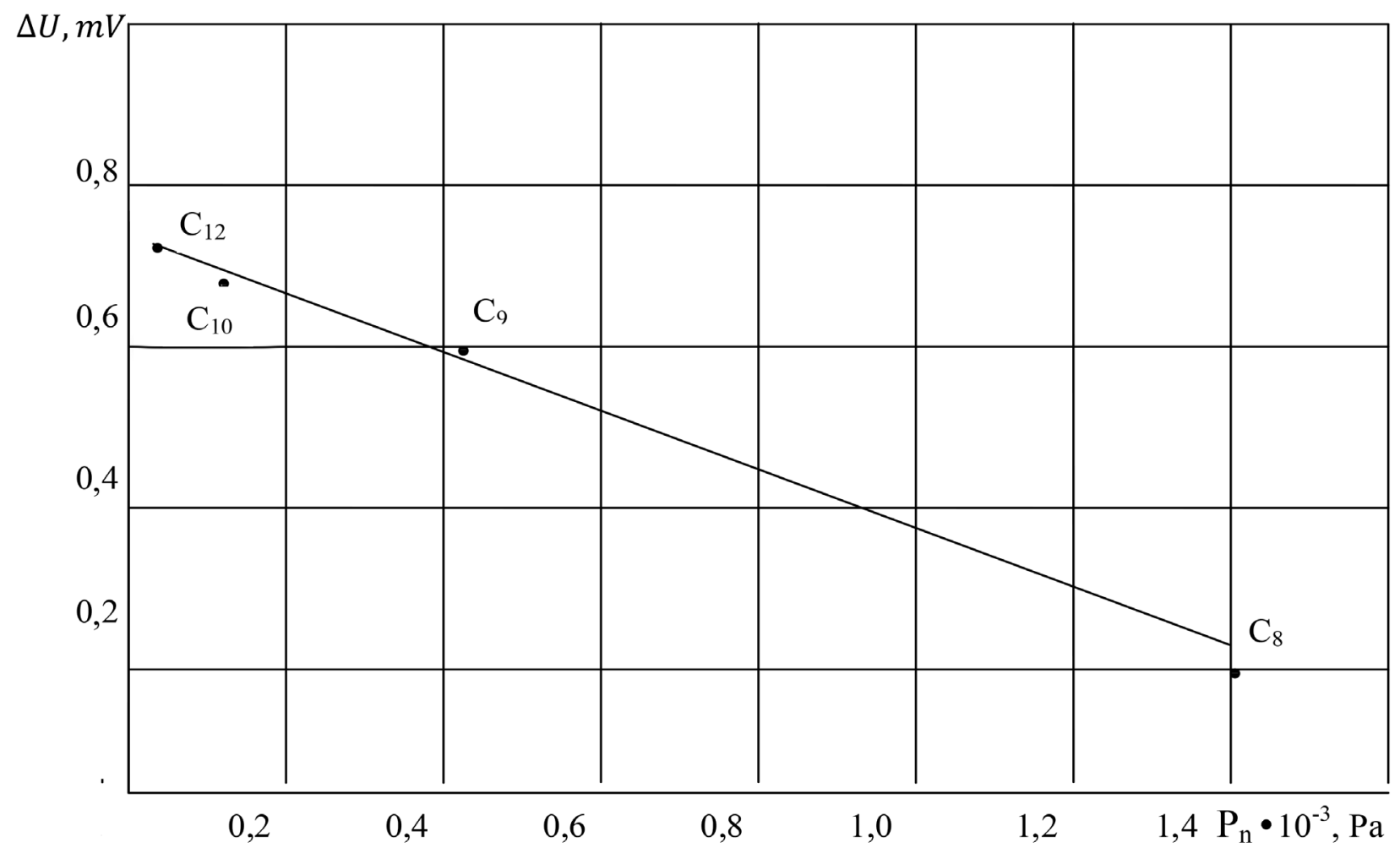

Fig. 2. Dependence of signal amplitude from saturated vapor pressure of the analyzed substance

The process of ozone formation in the barrier discharge proceeds in two stages. At the first stage, endothermic dissociation of oxygen molecules occurs to atoms, and at the second exothermic stage, a reversible reaction of ozone formation takes place.

During electro-cracking in the environment of hydrocarbons gas in the barrier discharge there is a splitting of molecules of hydrocarbons to the radicals, the recombination of which leads to formation of acetylene, its homologues, soot, hydrogen, and a certain amount of ethylene [5,6].

The nature of chemical reactions and, therefore, composition of reaction products are defined by preliminary composition of initial substances, their pressure, time of impact of electric discharge and its power.

At the interaction of atomic oxygen with products of electro-cracking of combustible substances, the balance in formation of ozone is broken that leads to decrease of concentration of ozone in the barrier discharge. Measuring the changes in ozone concentration at the output of the barrier discharge in the presence of combustible substances in the air entering the barrier discharge, one can indirectly judge their concentration [7].

The research was conducted at the experimental bench assembled according to the scheme provided in Fig. 1. The analyzed sample of the combustible substance (liquid hydrocarbons or petroleum products) was introduced into the pre-washed glass 2 with an internal diameter of $30 \mathrm{~mm}$ of the evaporation chamber 3, placed in the thermostat
4, through the injection unit using a syringe. At this, the volume of gas space, at input of a dose of $10 \mathrm{~cm}^{3}$, did not exceed $20 \mathrm{~cm}^{3}$.

In the analysis of substances within 2-3 minutes, the evaporation chamber was blowing through with air from the air preparation unit 1 . During the specified time interval, the gas phase saturated with vapors of the analyzed substance comes to interelectrode space of a synthesizer of ozone. At the flowing of air saturated with vapors of combustible substances between two coaxially located metal electrodes in the form of a tube 6 and a rod 8 divided by a dielectric 7 , plasmachemical processes take place, the result of which is a decrease of concentration of ozone at the output of the synthesizer. Then the air ozonized in similar conditions comes to the analytical measuring converter 11 where the dose of test substance (propylene) simultaneously inflows. At this, an ozonolysis reaction occurs between ozone and propylene, followed by heat effect. The generated heat is measured by the thermos converter 12. As a result, at the output of the measuring converter placed in the thermostat 10 , electric signals that are registered in the form of a chromatographic impulse on the chart of the recorder 14 are formed. Amplitude of impulses is proportional to pressure of saturated vapors of combustible substances. The dosing of the test substance is carried out by means of an automatic dispenser 16 controlled by the command device 15. After the analysis is finished, the glass 2 is 
unscrewed, cleaned of the analyzed substance and re-screwed into the evaporation chamber 3 up to the stop. Then the evaporation chamber and the ozone synthesizer are being blown through with clean air for two minutes.

Fluid hydrocarbons with number of atoms of carbon from $\mathrm{C}_{8}$ to $\mathrm{C}_{15}$ were analyzed in research. Dependence between amplitude of a signal $\Delta U$ of the measuring converter from pressure of saturated vapors $\mathrm{Pn}$ of the analyzed substance is shown in Fig. 2.
The results of the research, which show the dependence of the signal amplitude from the measuring transducer and the temperature of the evaporation chamber, are given in Table. As can be seen from Table, the signal of the measuring transducer decreases with the increasing of the temperature of the evaporation chamber, as the saturated vapor pressure of the substances under study increases, which leads to a decrease in ozone concentration at the output of the ozone synthesizer.

Dependence between the amplitude of the signal of the measuring transducer and the temperature of the evaporating chamber

\begin{tabular}{|c|c|c|}
\hline Analyzed substance & $\begin{array}{c}\text { The temperature of the evaporative } \\
\text { camera, }{ }^{\circ} \mathrm{C}\end{array}$ & $\begin{array}{c}\text { Amplitude of the signal of the measuring } \\
\text { converter, } m V\end{array}$ \\
\hline \multirow{2}{*}{$\mathrm{C}_{8} \mathrm{H}_{18}$} & 10 & 0,43 \\
\cline { 2 - 3 } & 20 & 0,18 \\
\hline \multirow{3}{*}{$\mathrm{C}_{9} \mathrm{H}_{20}$} & 20 & 0,6 \\
\cline { 2 - 3 } & 30 & 0,45 \\
\hline \multirow{2}{*}{$\mathrm{C}_{10} \mathrm{H}_{22}$} & 40 & 0,2 \\
\cline { 2 - 3 } & 20 & 0,67 \\
\cline { 2 - 3 } & 30 & 0,6 \\
\cline { 2 - 3 } & 40 & 0,54 \\
\cline { 2 - 3 } & 50 & 0,4 \\
\hline \multirow{2}{*}{$\mathrm{C}_{12} \mathrm{H}_{26}$} & 60 & 0,2 \\
\cline { 2 - 3 } & 40 & 0,72 \\
\cline { 2 - 3 } & 50 & 0,7 \\
\cline { 2 - 3 } & 60 & 0,66 \\
\hline
\end{tabular}

\section{Conclusion}

It was shown that the reaction of modulation the concentration of ozone by the concentration of vapors of liquid hydrocarbons and petroleum products in air directly in the ozone synthesizer makes it possible to use the method of analytical control under consideration to measure the pressure of saturated vapors of liquid hydrocarbons and petroleum products, and to control the composition of vapor-gas mixtures of combustible substances and fuels. The proposed method has sufficient high sensitivity and the possibility of analysis in a discrete-continuous mode of indicators of the quality of petroleum products.

\section{Комбинированный метод аналитического контроля концентрации горючих веществ с предварительным окислением в барьерном разряде}

\section{Г.М. Мамедов, С.М. Аббасова}

Азербайджанский государственный университет нефти и промышленности, пр-m Азадлые, 20, 1010, Баку, Азербайджан mamedov.gakhraman@mail.ru

\section{Аннотация}

Рассматривается комбинированный метод аналитического контроля концентрации горючих веществ с предварительным окислением в барьерном разряде, где анализируемое вещество подвергается совокупности 
определенных видов энергетических воздействий, что позволяет получить измерительную информацию о составе или физико-химических свойствах анализируемого вещества. В аналитической практике в барьерном разряде синтезируется озон в устройстве, представляющем собой разделенные диэлектриком из пиритового стекла два коаксиально расположенных металлических электрода в виде трубки и стержня, промежуток которых заполнен воздухом под атмосферным давлением. Процесс получения озона в устройстве протекает в две стадии. На первой стадии происходит эндотермическая диссоциация молекул кислорода на атомы, а на второй (экзотермической) стадии - обратимая реакция образования озона.

При электрокрекинге в среде газообразных углеводородов в барьерном разряде происходит расщепление молекул углеводородов на радикалы. Характер химических реакций, а следовательно, и состав продуктов реакции определяются первоначальным составом исходных веществ, их давлением, а также временем воздействия электрического разряда и его мощностью. При взаимодействии атомарного кислорода с продуктами электрокрекинга молекул анализируемых веществ нарушается баланс в образовании озона, что приводит к уменьшению концентрации озона в барьерном разряде.

Изменение концентрации озона в присутствии паров жидких углеводородов и нефтепродуктов в воздухе, непосредственно в синтезаторе озона, позволяет использовать рассматриваемый метод аналитического контроля для определения концентрации парогазовых смесей горючих веществ и нефтепродуктов, а также измерения давления насыщенных паров жидких углеводородов, нефтепродуктов и топлив.

Ключевые слова: барьерный разряд, окисление, озон, атомарный кислород, горючее вещество, давление насыщенных паров, концентрация.

\section{Комбінований метод аналітичного контролю концентрації горючих речовин із попереднім окисленням у бар'єрному розряді}

\section{Г.М. Мамедов, С.М. Аббасова}

Азербайджанський державний університет нафрти та промисловості, пр-т Азадлие, 20, 1010, Баку, Азербайджан mamedov.gakhraman@mail.ru

\section{Анотація}

Розглядаєься комбінований метод аналітичного контролю концентрації горючих речовин 3 попереднім окисленням у бар'єрному розряді, де речовина, що аналізується, піддається сукупності певних видів енергетичних впливів, що дозволяє отримати вимірювальну інформацію щодо складу або фізико-хімічних властивостей речовини, що аналізується. В аналітичній практиці в бар'єрному розряді синтезується озон у пристрої, що являє собою розділені діелектриком із піритового скла два коаксіально розташованих металевих електроди у вигляді трубки і стрижня, проміжок яких заповнено повітрям під атмосферним тиском. Процес отримання озону в пристрої протікає у дві стадії. На першій стадії відбувається ендотермічна дисоціація молекул кисню на атоми, а на другій (екзотермічній) стадії - оборотна реакція утворення озону.

При електрокрекінгу в середовищі газоподібних вуглеводнів у бар'єрному розряді відбувається розщеплення молекул вуглеводнів на радикали. Характер хімічних реакцій, а отже, і склад продуктів реакції визначаються початковим складом вихідних речовин, їхнім тиском, а також часом впливу електричного розряду і його потужністю. При взаємодії атомарного кисню з продуктами електрокрекінгу молекул речовин, що аналізуються, порушується баланс в утворенні озону, що приводить до зменшення концентрації озону в бар'єрному розряді.

Зміна концентрації озону в присутності парів рідких вуглеводнів і нафтопродуктів у повітрі, безпосередньо в синтезаторі озону, дозволяє використовувати цей метод аналітичного контролю для визначення концентрації парогазових сумішей горючих речовин і нафтопродуктів, а також вимірювання тиску насичених парів рідких вуглеводнів, нафтопродуктів і палив.

Ключові слова: бар'єрний розряд, окислення, озон, атомарний кисень, горюча речовина, тиск насичених парів, концентрація. 


\section{References}

1. Begunov A.A., Konopel'ko L.A. Fiziko-himicheskie izmerenija sostava $i$ svojstva veshhestv [Physico-chemical measurements of composition and properties of substances]. Moscow, Izd-vo standartov, 1984. $144 \mathrm{p}$.

2. Aleskovskij V.B., Bardin V.V., Bulatov M.I. et al. (Eds.). Fiziko-himicheskie metody analiza. Prakticheskoe rukovodstvo: uchebnoe posobie dlya vuzov [Physicochemical methods of analysis. Practical Guide: A tutorial for universities]. Leningrad, Himiya, 1988, 376 p. (in Russian).

3. Ishhenko A.A. (Ed.). Analitcheskaja himija $i$ fiziko-himicheskie metody analiza [Analytical chemistry and physicochemical methods of analysis]. Vol. 1, 2. Moscow, Izdatelskij centr "Akademiya", 2014. 352 p.

4. B.V. Stoljarov, I. M. Savinov, A. G. Vitenberg et al. (Eds.). Prakticheskaja gazovaja i zhidkostnaya hromatografiya [Practical gas and liquid chromatography]. St. Petersburg, Izd-vo St.-Peterburgskogo gos. universiteta, 1998. $612 \mathrm{p}$.

5. Razumovskij S. D., Zaikov G. E. Ozon i ego reakcii s organicheskimi soedineniyami [Ozone and its reactions with organic compounds]. Moscow, Nauka, 1974. 322 p.

6. Galstyan G. A., Tyupalo N.F., Razumovskij S.D. Ozon i ego reakcii s aromaticheskimi soedinenijami v zhidkoj faze [Ozone and its reactions with aromatic compounds in the liquid phase]. Lugansk, STI, 2004. 20 p.

7. Azim-zade A. Yu., Farzane N.G., Ilyasov L.V., Mamedov G. M. Datchik koncentrasii parov uglevodorodnykh topliv [Vapor concentration sensor for hydrocarbon fuels]. Patent SSSR, no. 1723510. Byulleten' izobretenij Publ., 1992, no. 12 (in Russian). 